\title{
PET Imaging of Neuroinflammation
}

\author{
Sujatha Kannan, $\mathrm{MD}^{1}$, Bindu Balakrishnan, $\mathrm{PhD}^{1}$, Otto Muzik, $\mathrm{PhD}^{1,2}$, Roberto Romero, \\ $\mathbf{M D}^{3,4}$, and Diane Chugani, $\mathbf{P h D}^{1,2}$ \\ ${ }^{1}$ Carman and Ann Adams Department of Pediatrics, Wayne State University School of Medicine, \\ Detroit, Michigan \\ ${ }^{2}$ Department of Radiology, Wayne State University School of Medicine, Detroit, Michigan \\ ${ }^{3}$ Department of Molecular Medicine and Genetics, Wayne State University School of Medicine, \\ Detroit, Michigan \\ ${ }^{4}$ Perinatology Research Branch, NICHD, NIH, DHHS
}

\begin{abstract}
Injury to the central nervous system is characterized by the localization of activated microglia at the site of injury. The peripheral benzodiazepine receptor (PBR) expressed on the outer mitochondrial membrane of the activated microglia is a sensitive biomarker for the detection of this neuroinflammatory response to an insult. PK11195, an isoquinoline ligand that specifically binds PBR, when tagged with a positron emitter can be used as a tracer for molecular imaging of this receptor in vivo by positron emission tomography. $\left[{ }^{11} \mathrm{C}\right](R) \mathrm{PK} 11195$ has been used in the imaging of various neuroinflammatory disorders such as Alzheimer's' and multiple sclerosis. Based on our small animal PET imaging studies using a neonatal rabbit model of maternal inflammation induced cerebral palsy, we propose that PET imaging using $\left[{ }^{11} \mathrm{C}\right](R) \mathrm{PK} 11195$ may be a valuable tool for detecting neuroinflammation in the brain of newborns born to mothers with chorioamnionitis.
\end{abstract}

\section{Introduction}

The inflammatory response in the brain has been implicated in the development of a number of neurodegenerative disorders both in the pediatric and adult age groups. Maternal intrauterine inflammation has been recognized as one of the causes of perinatal brain injury leading to periventricular leukomalacia resulting in lifelong disabilities such as cerebral palsy and cognitive impairment in the infant ${ }^{1}$. Recent evidence has shown that activated microglia may have a role to play in the development of white matter injury in the perinatal period $^{2,3,4}$. Intrauterine infection may lead to a fetal systemic inflammatory response mediated by cytokines resulting in the activation of microglial cells in the fetal brain. Microglial cells, when activated by pro-inflammatory cytokines release oxidative and nitrosative products, and excitotoxic metabolites that can cause damage to the surrounding oligodendrocytes 5,6 . This neuroinflammatory response to perinatal insults can be detected at an early stage by positron emission tomography (PET), using ligands that are specific for the peripheral benzodiazepine receptors expressed by microglial cells. This review focuses on the characteristics of the inflammatory response in the CNS that make it amenable for detection by PET imaging, along with reviewing its current applications in the detection of

Corresponding author: Sujatha Kannan, MD, Children's Hospital of Michigan, Carman \& Ann Adams Department of Pediatrics, Wayne State University, 3901 Beaubien Blvd. Detroit, MI 48201, Ph: (313) 745-5629; Fax: (313) 966-0105,

skannan@med.wayne.edu.

Presented at the Neurobiology of Disease in Children Conference in Santa Clara, CA, November 2009. 
various neurodegenerative and neuroinflammatory disorders in animal models and in patients. We have also discussed the potential applications of PET imaging in detecting neuroinflammation induced by perinatal brain injury in the neonatal period.

\section{Role of microglial cells in neuroinflammation}

Microglia constitute about $10-12 \%$ of the total cells of the brain ${ }^{7}$ and are located in the white matter and predominantly in the grey matter including hippocampus, olfactory telencephalon, basal ganglia and substantia niagra in the normal adult brain ${ }^{8}$. In the healthy brain, microglia interacts with other cortical elements like astrocytes, neurons and blood vessels, thereby monitoring neuronal well being. The resident microglia are characterized by ramified morphology and spiky protrusions ${ }^{9}$.They are highly dynamic structures and can sense subtle changes in their microenvironment with their motile processes and protrusions ${ }^{10}$. On activation following an injury, microglia undergo a pronounced change in morphology from ramified to an amoeboid structure presumably serving an immune surveillance function. Activated microglia secrete proinflammatory mediators like prostaglandins, TNF a, IL-1ß,chemokines, reactive oxygen species, nitric oxide and antiinflammatory substances like IL10 and neurotrophic factors ${ }^{9}$. In the developing brain microglia are predominantly seen in the white matter tracts from late second trimester onwards till term, decreasing in density in the postnatal period but present in low densities in the white matter tracts until two years of age. The microglia then migrate to the cortex where they are found mostly during adulthood, taking on their typical ramified form ${ }^{11}$.

Though it is still not clear if the presence of activated microglia in many neuroinflammatory disorders is the cause or the effect, its detection can be used as a reliable biomarker for brain injury. Activated microglial cells express the peripheral benzodiazepine receptor on the outer membrane of the mitochondria that can be used as a sensitive marker for the presence of neuroinflammation.

\section{Role of inflammation in neurological disorders}

The inflammatory response of the central nervous system (CNS) to various types of injuries is dominated by the presence of activated microglia and astrocytes (reactive gliosis) at the site of injury ${ }^{12,13}$ Even though the primary goal of this neuroinflammatory response may be related to repair and regeneration, it can act as a double edged sword attenuating the neuronal injury on one hand, while on the other hand exacerbating the underlying pathology. This neuroinflammatory process may also disrupt the blood-brain barrier (BBB), resulting in the entry of cells such as peripheral macrophages and neutrophils from the bloodstream at the site of injury ${ }^{14}$. Microglial cells can act as both the target and source of proinflammatory cytokines ${ }^{15}$ and have been implicated in the development and progression of various neurodegenerative and neuroinflammatory disorders such as multiple sclerosis, Parkinsons' disease, Alzheimer's, experimental autoimmune encephalitis etc 16,17,18,19.

The role of microglia in neurodegenerative disorders such as Alzheimer's has been investigated extensively. In vivo imaging and quantitative morphological analysis in transgenic mice have demonstrated that microglia can aggregate around amyloid plaques and phagocytose A $\beta$ proteins ${ }^{20}$. Microglia isolated from aged transgenic PS1 APP mice exhibited marked reduction of $A \beta$ binding scavenger receptors and $A \beta$-degrading enzymes along with an increase in the proinflammatory cytokines IL-1 (interleukin-1 $\beta$ ) and tumor necrosis factor $\alpha$ (TNFa) thereby setting the stage for disease progression ${ }^{21}$. Similarly in Parkinsons' disease, even though the etiology of the disease remains largely elusive, presence of an enduring neuroinflammation is strongly suspected with activated microglia found in close proximity to degenerating dopaminergic neurons ${ }^{22}$ 
In the pediatric age group, microglial activation has been implicated in having a role in the development of disorders such as epilepsy, autism, leukodystrophies and chorioamnionitis induced cerebral palsy $1,23,24,25$. Activated microglia have been detected in children with encephalitis and intractable seizures and also in animal models of seizures induced by excitotoxic metabolites $26,27,28$. An active neuroinflammatory response characterized by microglial activation and astroglia was noted in the cerebral cortex, white matter and cerebellum of patients with autism along with increased CSF expression of inflammatory cytokines ${ }^{25}$. An increased expression of pro-inflammatory cytokines co-localizing with the presence of activated microglia, astrocytes and globoid cells was noted in macaques affected by globoid cell leukodystrophy ${ }^{29}$. Inflammatory infiltrates involving activated microglia were also noted in the brain of patients with X-linked adrenoleukodystrophy ${ }^{30}$.

\section{Neuroinflammation in Cerebral Palsy}

A number of clinical studies have noted the significant correlation between intrauterine inflammation, perinatal brain injury and cerebral palsy 31,32 . Clinical evidence indicates that the presence of periventricular leukomalacia (PVL) is one of the most identifiable risk factors for developing cerebral palsy ${ }^{33}$. PVL may be focal, characterized by areas of necrosis in the deep white matter near the ventricles or diffuse throughout the cerebral white matter with injury to developing oligodendrocytes and presence of activated microglial cells ${ }^{34,35,36}$. In recent years a number of in vitro and in vivo studies have implicated microglial cells in the development of PVL. Haynes et al. ${ }^{34}$ have shown the increased presence of activated microglia diffusely throughout the white matter in autopsy specimens of patients with periventricular leukomalacia (PVL) indicating that microglia are involved in causing white matter damage by oxidative and nitrosative stress. Several compelling studies have shown the correlation between elevated amniotic fluid concentrations of cytokines and the subsequent development of PVL and cerebral palsy ${ }^{37,38}$. Pro-inflammatory cytokines such as IL-1 $\beta$ and TNF- $\alpha$ have been found in high concentrations in the amniotic fluid of women with preterm labor and intra-amniotic fluid infection ${ }^{39}$. High levels of TNF-a, IL-1 $\beta$ and IL- 6 have been detected in the blood of neonates that develop spastic cerebral palsy ${ }^{40}$. Infants with PVL and a history of infection have high cerebral cytokine levels such as TNF- $\alpha$ and IL- $1 \beta^{41}$. Pro-inflammatory cytokines such as IL-1 $\beta$ and TNF- $\alpha$ have been shown to induce microglial activation in vitro ${ }^{42}$. The fetal inflammatory response following intra-uterine infection/inflammation may lead to activation and recruitment of microglial cells present in the white matter regions of the fetal brain, subsequently resulting in widespread production of pro-inflammatory mediators leading to the death of surrounding oligodendrocytes and hence white matter injury (Figure 1). In vitro studies supporting the role of microglial cell activation in white matter injury have shown that LPS treatment results in oligodendrocyte damage only in the presence of microglial cells ${ }^{43}$. Activated microglial cells may induce oligodendrocyte injury by releasing superoxides and peroxynitrites ${ }^{6}$, excitotoxic metabolites such as glutamate and quinolinic acid that may cause glutamate receptor, or NMDA receptor mediated injury to oligodendrocytes ${ }^{5}$, and by producing a variety of pro-inflammatory cytokines many of which are cytotoxic ${ }^{44}$. Studies have demonstrated selective white matter lesions in fetal and neonatal animals after local, systemic, or intrauterine administration of LPS 45 .

Activated microglia express toll like receptors (TLR) that are pivotal for recognizing microbial motifs expressed by a wide array of pathogens ${ }^{46}$. The TLR 4 receptors on microglia recognizes the bacterial lipopolysaccharide and are essential for lipopolysaccharadide induced oligodendrocyte death ${ }^{43}$. It is shown that peroxynitrite, a short-lived potent oxidant and the reaction product of nitric oxide (NO) and superoxide, is the toxic microglial factor responsible for LPS-induced death of preOLs ${ }^{6}$.The low resistance of oligodendrocytes to oxidative stress, presence of calcium permeable glutamate 
receptors and the presence of NMDA receptors in their myelinating processes make them highly susceptible for injury 47,48 . Studies in our lab have shown that intrauterine administration of endotoxin to pregnant rabbits near term led to a robust activation of microglial cells confined to the periventricular white matter regions of the newborn rabbit brain that was associated with a phenotype of cerebral palsy and hypomyelination in the neonate ${ }^{4}$. Dammann et al ${ }^{31}$ have proposed that PVL and CP may develop as a result of an ongoing inflammatory process as evidenced by the presence of inflammatory markers weeks after birth and activated microglia on autopsy even in adults with perinatal brain injury.

\section{Peripheral Benzodiazepine Receptor or Translocator protein 18kDA: A biomarker for activated microglia}

The peripheral benzodiazepine binding sites (PBBS) or receptors (PBR) are multimeric protein complexes comprising of three subunits ${ }^{49}$. These binding sites were originally discovered in rat kidneys because diazepam was found to bind these receptors with high affinity ${ }^{50}$. Although these sites bind benzodiazepines, they are pharmacologically and structurally different from the central benzodiazepine receptors with different physiological functions ${ }^{51}$. Due to its significant difference from the central benzodiazepine receptors, it has been proposed that the nomenclature of the PBR should be changed to translocator protein $18 \mathrm{kDA}$ (TSPO) to be more reflective of its function ${ }^{52}$. These sites are now known to comprise of the $18 \mathrm{kDa}$ receptor protein, the $32 \mathrm{kDa}$ voltage-dependent anion channel receptor protein required for benzodiazepine binding, and the $30 \mathrm{kDa}$ adenine nucleotide carrier 51,53 . They are most commonly located in the outer mitochondrial membrane of activated microglia in the brain ${ }^{54}$ and have been used as a sensitive marker to visualize and measure glial cell activation associated with various neuroinflammatory disorders $26,55,56$. Though the exact function of the peripheral benzodiazepine receptor has not been clearly elucidated, it appears that PBR is involved in the regulation of cell death ${ }^{57}$, mitochondrial respiration ${ }^{58}$, cell growth and proliferation ${ }^{59}$, steroidogenesis 53 , and chemotaxis and cellular immunity 60,61 . The normal healthy brain does not express peripheral benzodiazepine binding sites except in areas such as the choroid plexus, ependymal layer and perivascular cells ${ }^{55}$. In the presence of brain injury, the activation of microglial cells is typically localized to the site of the injured neuron with extension along the anterograde or retrograde axonal pathway. This characteristic response helps localize the site and distribution of injury accurately when imaging activated microglia providing information about the temporal and spatial progression of various neuroinflammatory disorders. Although in vitro studies have shown that PBR expression may be seen both in astrocytes and micorglia, many in vivo studies have shown that the increased expression of PBR following an injury has primarily correlated most consistently with the presence of activated microglial cells 26,62,63. The extent of PBR expression appears to be directly related to the extent of injury with a large increase noted in the case of frank neuronal loss and smaller increases noted with just the loss of neuronal terminals 64,65 . Detection of PBR expression also appears to be a more sensitive indicator of brain injury leading to an increase even before histological changes such as neuronal apoptosis or loss are noted 64

Benzodiazepines such as 7-chloro-5-(4-chlorophenyl)-1-methyl-1,3dihydrobenzo[1,4]diazepin-2-one (Ro5-4864) bind the peripheral benzodiazepine receptor with nanomolar affinity with weaker affinity for the central benzodiazepine receptors. Other classes of compounds such as isoquinolines, phenoxyphenyl acetamides, pyrazolopyrimidine, indoleacetamide, and imidiazopyridines also bind PBR having the potential to be developed as biomarkers for the presence of activated microglial cells in brain injury 66,67 . 


\section{PET imaging of activated microglial cells with $\left[{ }^{11} \mathrm{C}\right](R)$ PK11195}

The constitutively low expression of PBRs in the normal brain with an increase in expression that is localized to the site of injury makes it an attractive biomarker for the detection of neuroinflammation and brain injury by imaging. Isoquinoline ligands such as PK11195 (1-[2-chlorophenyl]- $N$-methyl- $N$-[1-methyl-propyl]-3-isoquinoline carboxamide) bind the $18 \mathrm{kDA}$ subunit of the peripheral benzodiazepine binding site ${ }^{68}$ that are expressed on activated microglial cells. When labeled with carbon-11, PK 11195 can be effectively used as a ligand for PET studies, indicating the presence of activated microglia in acute inflammatory and neurodegenerative disorders ${ }^{56,62,69}$ (Table 1). The $(R)$ enantiomer has been shown to have higher affinity for the peripheral benzodiazepine binding sites than the $(S)$ enantiomer ${ }^{70}$ and, therefore, the $\left[{ }^{11} \mathrm{C}\right](R)$-PK11195 is used in most studies. In our study, we have demonstrated an increase in the retention of $\left[{ }^{11} \mathrm{C}\right](R) \mathrm{PK} 11195$ indicating specific binding of the tracer to peripheral benzodiazepine receptors in activated microglial cells in the newborn rabbit brain exposed to endotoxin in utero. (Figure 2). The increase in $\left[{ }^{11} \mathrm{C}\right](R) \mathrm{PK} 11195$ retention also correlates with our immunohistological studies, which demonstrates a change in morphology from ramified to ameoboid microglia (Figure 3a) and a robust increase in amoeboid microglial cells in the periventricular white matter regions in these animals ${ }^{4,71}$ (Figure $3 b$ ). The longitudinal assessment of $\left[{ }^{11} \mathrm{C}\right]$ PK11195 binding kinetics can be used as an effective tool in following the evolution of microglial activation in PVL and to determine the optimal time period for institution of therapy and to follow response to treatment.

$\left[{ }^{11} \mathrm{C}\right](R)$-PK11195 PET imaging in animal models of disease in models of Parkinson's disease, cuprizone -induced demyelination, traumatic brain injury, stroke and cerebral palsy have been useful for demonstrating the presence of activated microglia in these models $63,71,72,73,74$. The use of small animal PET provides a unique approach for conducting longitudinal studies in the same animal to determine the temporal progression of the disease and to monitor response to novel therapies.

The ligand PK11195 is effective in determining the cellular response in CNS pathology due to the fact that its entry into the brain from the blood is rapid and is not dependent on the blood brain barrier ${ }^{75}$. The in vivo PET signal and hence quantification of PK11195 binding may vary depending upon the cerebral blood flow which may be increased in certain regions due to inflammation or decreased globally due to sepsis and poor cardiac output. Changes in blood brain barrier permeability and recruitment of peripheral macrophages may also dictate the amount of tracer uptake in the brain. Lammertsma and Hume et al ${ }^{76}$ used a simplified reference tissue model to determine the binding potential of 11C PK11195, in which the ratio of the rate constant with which the tracer binds in the diseased region to a reference healthy area and the rate constant of dissociation or wash-out from these regions, is calculated in order to estimate the specific binding of the tracer in the affected region. In our animal model due to the small size of the brain and potential errors in manually defining disease free regions, a semi-quantitative estimation of specific binding was determined by comparing $\left[{ }^{11} \mathrm{C}\right](R)$ PK11195 retention in the whole brain over time, in the newborns with neuroinflammation versus the controls ${ }^{71}$.

Recently, tracers developed using other ligands such as $\left[{ }^{11} \mathrm{C}\right]$ DAA1106 [a phenoxyphenyl acetamide derivative, $\mathrm{N}$-(2,5-dimethoxybenzyl)- $\mathrm{N}$-(5-fluoro-2-phenoxyphenyl) acetamide], $\left[{ }^{11} \mathrm{C}\right]$ CLINME [ an acetamide derivative, 2-(6-chloro-2-(4-iodophenyl)-imidazo(1,2a)pyridine-3-yl)-N-ethyl-N-methyl-acetamide], and $\left[{ }^{11} \mathrm{C}\right.$ ] DPA-713 [a pyrazolopyrimidine derivative, N, N-diethyl-2-(2-(4-methoxyphenyl)-5,7-dimethyl-pyrazolo(1,5-a)pyrimidin-3yl)-acetamide $]$ have been shown to have a greater affinity to the PBR than $\left[{ }^{11} \mathrm{C}\right]$ PK11195 with less signal to noise ratio ${ }^{74,77}$. 


\section{Clinical Application of $\left[{ }^{11} \mathrm{C}\right](R) \mathrm{PK} 11195$ imaging in perinatal brain injury}

Amoeboid microglial cells accumulate in the immature white matter through the end of the second trimester until term as part of normal development decreasing in density towards term but maintaining their morphology even in early infancy (Chugani et al 1991) ${ }^{11,78}$. These microglial cells eventually migrate towards the cortex where they are found during adulthood ${ }^{11}$. Hence, activation of microglia that are normally present in the white matter tracts may make the fetal brain particularly vulnerable for white matter injury during gestation and around term.

Detection of activated microglial cells in vivo can provide valuable information about the degree of injury sustained in the perinatal period. Neonates born to mothers with chorioamnionitis either diagnosed clinically or by placental histopathology, can be screened by PET imaging with $\left[{ }^{11} \mathrm{C}\right](R) \mathrm{PK} 11195$ for the presence of activated microglial cells as an indicator of neuroinflammation and hence possible predictor for the development of brain injury secondary to intrauterine infection. Though large radiation exposures in the neonatal period is a matter for concern, with regard to the radiation dose, $\left[{ }^{11} \mathrm{C}\right](R) \mathrm{PK} 11195$ scans in neonates could be accomplished using effective doses approximately equal to the yearly background radiation exposure, and less than or equal to the exposure of a clinical CT scan of the head. CT scans currently result in an effective dose of around 30-90 mSv (3.0-9.0 rem) per scan to the organ scanned ${ }^{79}$. At these doses in the newborn period there is a small risk of radiation associated cancer of around $0.04-0.06 \%$ lifetime attributable risk with the above exposure ${ }^{79}$. This risk decreases substantially with a decrease in the dose used. With the PET scan the typical neonatal doses would be around $5 \mathrm{mSv}$ which is 6-18 times less than that reported with CT scans. Given the very serious debilitating consequences of the development of cerebral palsy from perinatal brain injury, PET scanning for early detection of neuroinflammation in the neonate may potentially have a high benefit to risk ratio. A noninvasive technique that would help detect the presence and progress of neuroinflammation at a very early stage would be beneficial in directing relevant supportive therapies and follow up for these patients. Judicious use of PET scanning in the neonatal period would also eventually help in the development of early therapeutic interventions that can be directed towards these patients.

\section{Conclusion}

Molecular imaging of the PBR provides a unique approach for detecting the presence and extent of brain injury in various neurodegenerative and neuroinflammatory disorders.

Although there has been increased interest in PET imaging for detection of neurodegenerative disorders in adults and older children, its potential applications in the neonatal period and during infancy have not been explored adequately. PET imaging for detection of neuroinflammation can be a valuable tool for non-invasively diagnosing the presence and extent of brain injury in newborns exposed to intrauterine insults. When used in conjunction with diffusion tensor imaging or magnetic resonance spectroscopy it can be used to detect subtle changes in the CNS that may not be obvious by conventional imaging techniques. PET imaging of neuroinflammation may be useful as a prognostic indicator for the development of white matter injury and cerebral palsy, and can also provide valuable information for monitoring the response to therapeutic strategies.

\section{Acknowledgments}

Financial Support: 
This research was supported (in part) by the Perinatology Research Branch, Division of Intramural Research, Eunice Kennedy Shriver National Institute of Child Health and Human Development, NIH, DHHS and by 5K08HD050652, NICHD.

\section{References}

1. Wu YW, Escobar GJ, Grether JK, et al. Chorioamnionitis and cerebral palsy in term and near-term infants. JAMA. 2003; 290:2677-2684. [PubMed: 14645309]

2. Bell MJ, Hallenbeck JM. Effects of intrauterine inflammation on developing rat brain. J Neurosci Res. 2002; 70:570-579. [PubMed: 12404511]

3. Cai Z, Pan ZL, Pang Y, et al. Cytokine induction in fetal rat brains and brain injury in neonatal rats after maternal lipopolysaccharide administration. Pediatr Res. 2000; 47:64-72. [PubMed: 10625084]

4. Saadani-Makki F, Kannan S, Lu X, et al. Intrauterine administration of endotoxin leads to motor deficits in a rabbit model: a link between prenatal infection and cerebral palsy. Am J Obstet Gynecol. 2008; 199:651-657. [PubMed: 18845289]

5. Espey MG, Chernyshev ON, Reinhard JF Jr, et al. Activated human microglia produce the excitotoxin quinolinic acid. Neuroreport. 1997; 8:431-434. [PubMed: 9080423]

6. Li J, Baud O, Vartanian T, et al. Peroxynitrite generated by inducible nitric oxide synthase and NADPH oxidase mediates microglial toxicity to oligodendrocytes. Proc Natl Acad Sci U S A. 2005; 102:9936-9941. [PubMed: 15998743]

7. Block ML, Zecca L, Hong JS. Microglia-mediated neurotoxicity: uncovering the molecular mechanisms. Nat Rev Neurosci. 2007; 8:57-69. [PubMed: 17180163]

8. Lawson LJ, Perry VH, Dri P, et al. Heterogeneity in the distribution and morphology of microglia in the normal adult mouse brain. Neuroscience. 1990; 39:151-170. [PubMed: 2089275]

9. Vilhardt F. Microglia: phagocyte and glia cell. Int J Biochem Cell Biol. 2005; 37:17-21. [PubMed: 15381143]

10. Nimmerjahn A, Kirchhoff F, Helmchen F. Resting microglial cells are highly dynamic surveillants of brain parenchyma in vivo. Science. 2005; 308:1314-1318. [PubMed: 15831717]

11. Billiards SS, Haynes RL, Folkerth RD, et al. Development of microglia in the cerebral white matter of the human fetus and infant. J Comp Neurol. 2006; 497:199-208. [PubMed: 16705680]

12. Dheen ST, Kaur C, Ling EA. Microglial activation and its implications in the brain diseases. Curr Med Chem. 2007; 14:1189-1197. [PubMed: 17504139]

13. Pekny M, Nilsson M. Astrocyte activation and reactive gliosis. Glia. 2005; 50:427-434. [PubMed: 15846805]

14. Lossinsky AS, Shivers RR. Structural pathways for macromolecular and cellular transport across the blood-brain barrier during inflammatory conditions. Histol Histopathol. 2004; 19:535-564. Review. [PubMed: 15024715]

15. O'Callaghan JP, Sriram K, Miller DB. Defining "neuroinflammation". Ann N Y Acad Sci. 2008; 1139:318-330. [PubMed: 18991877]

16. Gray E, Thomas TL, Betmouni S, et al. Elevated activity and microglial expression of myeloperoxidase in demyelinated cerebral cortex in multiple sclerosis. Brain Pathol. 2008; 18:8695. [PubMed: 18042261]

17. Mosley RL, Benner EJ, Kadiu I, et al. Neuroinflammation, Oxidative Stress and the Pathogenesis of Parkinson's Disease. Clin Neurosci Res. 2006; 6:261-281. [PubMed: 18060039]

18. Rojo LE, Fernandez JA, Maccioni AA, et al. Neuroinflammation: implications for the pathogenesis and molecular diagnosis of Alzheimer's disease. Arch Med Res. 2008; 39:1-16. [PubMed: 18067990]

19. Crocker SJ, Whitmire JK, Frausto RF, et al. Persistent macrophage/microglial activation and myelin disruption after experimental autoimmune encephalomyelitis in tissue inhibitor of metalloproteinase-1-deficient mice. Am J Pathol. 2006; 169:2104-2116. [PubMed: 17148673]

20. Bolmont T, Haiss F, Eicke D, et al. Dynamics of the microglial/amyloid interaction indicate a role in plaque maintenance. J Neurosci. 2008; 28:4283-4292. [PubMed: 18417708] 
21. Hickman SE, Allison EK, El KJ. Microglial dysfunction and defective beta-amyloid clearance pathways in aging Alzheimer's disease mice. J Neurosci. 2008; 28:8354-8360. [PubMed: 18701698]

22. Fahn, S.; Przedborski, S. Merritt's Neurology. Rowland, LP., editor. New York: Lippincott; 2000. p. 679-693.

23. Jaseja H. Cerebral palsy: Interictal epileptiform discharges and cognitive impairment. Clin Neurol Neurosurg. 2007; 109:549-552. [PubMed: 17574734]

24. Francalanci P, Eymard-Pierre E, Dionisi-Vici C, et al. Fatal infantile leukodystrophy: a severe variant of CACH/VWM syndrome, allelic to chromosome 3q27. Neurology. 2001; 57:265-270. [PubMed: 11468311]

25. Vargas DL, Nascimbene C, Krishnan C, et al. Neuroglial activation and neuroinflammation in the brain of patients with autism. Ann Neurol. 2005; 57:67-81. [PubMed: 15546155]

26. Banati RB, Goerres GW, Myers R, et al. [11C](R)-PK11195 positron emission tomography imaging of activated microglia in vivo in Rasmussen's encephalitis. Neurology. 1999; 53:2199_ 2203. [PubMed: 10599809]

27. Kumar A, Chugani HT, Luat A, et al. Epilepsy surgery in a case of encephalitis: use of 11CPK11195 positron emission tomography. Pediatr Neurol. 2008; 38:439-442. [PubMed: 18486829]

28. Taniwaki Y, Kato M, Araki T, et al. Microglial activation by epileptic activities through the propagation pathway of kainic acid-induced hippocampal seizures in the rat. Neurosci Lett. 1996; 217:29-32. [PubMed: 8905732]

29. Borda JT, Alvarez X, Mohan M, et al. Clinical and immunopathologic alterations in rhesus macaques affected with globoid cell leukodystrophy. Am J Pathol. 2008; 172:98-111. [PubMed: 18165263]

30. McGuinness MC, Powers JM, Bias WB, et al. Human leukocyte antigens and cytokine expression in cerebral inflammatory demyelinative lesions of X-linked adrenoleukodystrophy and multiple sclerosis. J Neuroimmunol. 1997; 75:174-182. [PubMed: 9143252]

31. Dammann O, Leviton A. Infection remote from the brain, neonatal white matter damage, and cerebral palsy in the preterm infant. Semin Pediatr Neurol. 1998; 5:190-201. [PubMed: 9777677]

32. O'Shea TM, Kothadia JM, Roberts DD, et al. Perinatal events and the risk of intraparenchymal echodensity in very-low-birthweight neonates. Paediatr Perinat Epidemiol. 1998; 12:408-421. [PubMed: 9805714]

33. Bejar RF, Vaucher YE, Benirschke K, et al. Postnatal white matter necrosis in preterm infants. J Perinatol. 1992; 12:3-8. [PubMed: 1560287]

34. Haynes RL, Folkerth RD, Keefe RJ, et al. Nitrosative and oxidative injury to premyelinating oligodendrocytes in periventricular leukomalacia. J Neuropathol Exp Neurol. 2003; 62:441-450. [PubMed: 12769184]

35. Volpe JJ. Neurobiology of periventricular leukomalacia in the premature infant. Pediatr Res. 2001; 50:553-562. [PubMed: 11641446]

36. Volpe JJ. Cerebral white matter injury of the premature infant-more common than you think. Pediatrics. 2003; 112:176-180. [PubMed: 12837883]

37. Martinez E, Figueroa R, Garry D, et al. Elevated Amniotic Fluid Interleukin-6 as a Predictor of Neonatal Periventricular Leukomalacia and Intraventricular Hemorrhage. J Matern Fetal Investig. 1998; 8:101-107.

38. Yoon BH, Romero R, Park JS, et al. Fetal exposure to an intra-amniotic inflammation and the development of cerebral palsy at the age of three years. Am J Obstet Gynecol. 2000; 182:675-681. [PubMed: 10739529]

39. Lonergan M, Aponso D, Marvin KW, et al. Tumor necrosis factor-related apoptosis-inducing ligand (TRAIL), TRAIL receptors, and the soluble receptor osteoprotegerin in human gestational membranes and amniotic fluid during pregnancy and labor at term and preterm. J Clin Endocrinol Metab. 2003; 88:3835-3844. [PubMed: 12915677]

40. Nelson KB, Dambrosia JM, Grether JK, et al. Neonatal cytokines and coagulation factors in children with cerebral palsy. Ann Neurol. 1998; 44:665-675. [PubMed: 9778266]

41. du Plessis AJ, Volpe JJ. Perinatal brain injury in the preterm and term newborn. Curr Opin Neurol. 2002; 15:151-157. [PubMed: 11923628] 
42. Hailer NP, Vogt C, Korf HW, et al. Interleukin-1beta exacerbates and interleukin-1 receptor antagonist attenuates neuronal injury and microglial activation after excitotoxic damage in organotypic hippocampal slice cultures. Eur J Neurosci. 2005; 21:2347-2360. [PubMed: 15932594]

43. Lehnardt S, Lachance C, Patrizi S, et al. The toll-like receptor TLR4 is necessary for lipopolysaccharide-induced oligodendrocyte injury in the CNS. J Neurosci. 2002; 22:2478-2486. [PubMed: 11923412]

44. Dommergues MA, Plaisant F, Verney C, et al. Early microglial activation following neonatal excitotoxic brain damage in mice: a potential target for neuroprotection. Neuroscience. 2003; 121:619-628. [PubMed: 14568022]

45. Hagberg H, Peebles D, Mallard C. Models of white matter injury: comparison of infectious, hypoxic-ischemic, and excitotoxic insults. Ment Retard Dev Disabil Res Rev. 2002; 8:30-38. [PubMed: 11921384]

46. Gurley C, Nichols J, Liu S, et al. Microglia and Astrocyte Activation by Toll-Like Receptor Ligands: Modulation by PPAR-gamma Agonists. PPAR Res. 2008; 2008:453120. [PubMed: 18584038]

47. Fern R, Moller T. Rapid ischemic cell death in immature oligodendrocytes: a fatal glutamate release feedback loop. J Neurosci. 2000; 20:34-42. [PubMed: 10627578]

48. Salter MG, Fern R. NMDA receptors are expressed in developing oligodendrocyte processes and mediate injury. Nature. 2005; 438:1167-1171. [PubMed: 16372012]

49. Garnier M, Boujrad N, Ogwuegbu SO, et al. The polypeptide diazepam-binding inhibitor and a higher affinity mitochondrial peripheral-type benzodiazepine receptor sustain constitutive steroidogenesis in the R2C Leydig tumor cell line. J Biol Chem. 1994; 269:22105-22112. [PubMed: 8071335]

50. Braestrup C, Squires RF. Specific benzodiazepine receptors in rat brain characterized by highaffinity (3H)diazepam binding. Proc Natl Acad Sci U S A. 1977; 74:3805-3809. [PubMed: 20632]

51. Gavish M, Bachman I, Shoukrun R, et al. Enigma of the peripheral benzodiazepine receptor. Pharmacol Rev. 1999; 51:629-650. [PubMed: 10581326]

52. Papadopoulos V, Baraldi M, Guilarte TR, et al. Translocator protein (18kDa): new nomenclature for the peripheral-type benzodiazepine receptor based on its structure and molecular function. Trends Pharmacol Sci. 2006; 27:402-409. [PubMed: 16822554]

53. Papadopoulos V, Widmaier EP, Amri H, et al. In vivo studies on the role of the peripheral benzodiazepine receptor (PBR) in steroidogenesis. Endocr Res. 1998; 24:479-487. [PubMed: 9888528]

54. Casellas P, Galiegue S, Basile AS. Peripheral benzodiazepine receptors and mitochondrial function. Neurochem Int. 2002; 40:475-486. [PubMed: 11850104]

55. Banati RB. Visualising microglial activation in vivo. Glia. 2002; 40:206-217. [PubMed: 12379908]

56. Gerhard A, Banati RB, Goerres GB, et al. [11C](R)-PK11195 PET imaging of microglial activation in multiple system atrophy. Neurology. 2003; 61:686-689. [PubMed: 12963764]

57. McEnery MW, Snowman AM, Trifiletti RR, et al. Isolation of the mitochondrial benzodiazepine receptor: association with the voltage-dependent anion channel and the adenine nucleotide carrier. Proc Natl Acad Sci U S A. 1992; 89:3170-3174. [PubMed: 1373486]

58. Hirsch JD, Beyer CF, Malkowitz L, et al. Mitochondrial benzodiazepine receptors mediate inhibition of mitochondrial respiratory control. Mol Pharmacol. 1989; 35:157-163. [PubMed: 2464128]

59. Wang JK, Morgan JI, Spector S. Benzodiazepines that bind at peripheral sites inhibit cell proliferation. Proc Natl Acad Sci U S A. 1984; 81:753-756. [PubMed: 6322168]

60. Lenfant M, Haumont J, Zavala F. In vivo immunomodulating activity of PK 1195, a structurally unrelated ligand for "peripheral" benzodiazepine binding sites--I. Potentiation in mice of the humoral response to sheep red blood cells. Int J Immunopharmacol. 1986; 8:825-828. [PubMed: 3023246]

61. Ruff MR, Pert CB, Weber RJ, et al. Benzodiazepine receptor-mediated chemotaxis of human monocytes. Science. 1985; 229:1281-1283. [PubMed: 2994216] 
62. Banati RB, Newcombe J, Gunn RN, et al. The peripheral benzodiazepine binding site in the brain in multiple sclerosis: quantitative in vivo imaging of microglia as a measure of disease activity. Brain. 2000; 123(Pt 11):2321-2337. [PubMed: 11050032]

63. Chen MK, Guilarte TR. Imaging the peripheral benzodiazepine receptor response in central nervous system demyelination and remyelination. Toxicol Sci. 2006; 91:532-539. [PubMed: 16554315]

64. Chen MK, Baidoo K, Verina T, et al. Peripheral benzodiazepine receptor imaging in CNS demyelination: functional implications of anatomical and cellular localization. Brain. 2004; 127:1379-1392. [PubMed: 15069023]

65. Kuhlmann AC, Guilarte TR. Cellular and subcellular localization of peripheral benzodiazepine receptors after trimethyltin neurotoxicity. J Neurochem. 2000; 74:1694-1704. [PubMed: 10737628]

66. Chen MK, Guilarte TR. Translocator protein $18 \mathrm{kDa}$ (TSPO): molecular sensor of brain injury and repair. Pharmacol Ther. 2008; 118:1-17. [PubMed: 18374421]

67. James ML, Selleri S, Kassiou M. Development of ligands for the peripheral benzodiazepine receptor. Curr Med Chem. 2006; 13:1991-2001. [PubMed: 16842193]

68. Papadopoulos V, Amri H, Boujrad N, et al. Peripheral benzodiazepine receptor in cholesterol transport and steroidogenesis. Steroids. 1997; 62:21-28. [PubMed: 9029710]

69. Gerhard A, Trender-Gerhard I, Turkheimer F, et al. In vivo imaging of microglial activation with [11C](R)-PK11195 PET in progressive supranuclear palsy. Mov Disord. 2006; 21:89-93. [PubMed: 16108021]

70. Shah F, Hume SP, Pike VW, et al. Synthesis of the enantiomers of [N-methyl-11C]PK 11195 and comparison of their behaviours as radioligands for PK binding sites in rats. Nucl Med Biol. 1994; 21:573-581. [PubMed: 9234314]

71. Kannan S, Saadani-Makki F, Muzik O, et al. Microglial activation in perinatal rabbit brain induced by intrauterine inflammation: detection with 11C-(R)-PK11195 and small-animal PET. J Nucl Med. 2007; 48:946-954. [PubMed: 17504871]

72. Black KL, Ikezaki K, Santori E, et al. Specific high-affinity binding of peripheral benzodiazepine receptor ligands to brain tumors in rat and man. Cancer. 1990; 65:93-97. [PubMed: 2152852]

73. Myers R, Manjil LG, Cullen BM, et al. Macrophage and astrocyte populations in relation to [3H]PK 11195 binding in rat cerebral cortex following a local ischaemic lesion. J Cereb Blood Flow Metab. 1991; 11:314-322. [PubMed: 1997503]

74. Venneti S, Wagner AK, Wang G, et al. The high affinity peripheral benzodiazepine receptor ligand DAA1106 binds specifically to microglia in a rat model of traumatic brain injury: implications for PET imaging. Exp Neurol. 2007; 207:118-127. [PubMed: 17658516]

75. Dumont F, De VF, Versijpt J, et al. In vivo evaluation in mice and metabolism in blood of human volunteers of [123I]iodo-PK11195: a possible single-photon emission tomography tracer for visualization of inflammation. Eur J Nucl Med. 1999; 26:194-200. [PubMed: 10079307]

76. Lammertsma AA, Hume SP. Simplified reference tissue model for PET receptor studies. Neuroimage. 1996; 4:153-158. [PubMed: 9345505]

77. Boutin H, Chauveau F, Thominiaux C, et al. 11C-DPA-713: a novel peripheral benzodiazepine receptor PET ligand for in vivo imaging of neuroinflammation. J Nucl Med. 2007; 48:573-581. [PubMed: 17401094]

78. Monier A, Adle-Biassette H, Delezoide AL, et al. Entry and distribution of microglial cells in human embryonic and fetal cerebral cortex. J Neuropathol Exp Neurol. 2007; 66:372-382. [PubMed: 17483694]

79. Brenner DJ, Hall EJ. Computed tomography--an increasing source of radiation exposure. N Engl J Med. 2007; 357:2277-2284. [PubMed: 18046031]

80. Okello A, Edison P, Archer HA, et al. Microglial activation and amyloid deposition in mild cognitive impairment: a PET study. Neurology. 2009; 72:56-62. [PubMed: 19122031]

81. Edison P, Archer HA, Gerhard A, et al. Microglia, amyloid, and cognition in Alzheimer's disease: An [11C](R)PK11195-PET and [11C]PIB-PET study. Neurobiol Dis. 2008; 32:412-419. [PubMed: 18786637] 
82. Cagnin A, Brooks DJ, Kennedy AM, et al. In-vivo measurement of activated microglia in dementia. Lancet. 2001; 358:461-467. [PubMed: 11513911]

83. van Berckel BN, Bossong MG, Boellaard R, et al. Microglia activation in recent-onset schizophrenia: a quantitative (R)-[11C]PK11195 positron emission tomography study. Biol Psychiatry. 2008; 64:820-822. [PubMed: 18534557]

84. Vas A, Shchukin Y, Karrenbauer VD, et al. Functional neuroimaging in multiple sclerosis with radiolabelled glia markers: preliminary comparative PET studies with [11C]vinpocetine and [11C]PK11195 in patients. J Neurol Sci. 2008; 264:9-17. [PubMed: 17727889]

85. Tai YF, Pavese N, Gerhard A, et al. Microglial activation in presymptomatic Huntington's disease gene carriers. Brain. 2007; 130:1759-1766. [PubMed: 17400599]

86. Pavese N, Gerhard A, Tai YF, et al. Microglial activation correlates with severity in Huntington disease: a clinical and PET study. Neurology. 2006; 66:1638-1643. [PubMed: 16769933]

87. Messmer K, Reynolds GP. Increased peripheral benzodiazepine binding sites in the brain of patients with Huntington's disease. Neurosci Lett. 1998; 241:53-56. [PubMed: 9502214]

88. Gerhard A, Pavese N, Hotton G, et al. In vivo imaging of microglial activation with [11C](R)PK11195 PET in idiopathic Parkinson's disease. Neurobiol Dis. 2006; 21:404-412. [PubMed: 16182554]

89. Ouchi Y, Yoshikawa E, Sekine Y, et al. Microglial activation and dopamine terminal loss in early Parkinson's disease. Ann Neurol. 2005; 57:168-175. [PubMed: 15668962]

90. Henkel K, Karitzky J, Schmid M, et al. Imaging of activated microglia with PET and [11C]PK 11195 in corticobasal degeneration. Mov Disord. 2004; 19:817-821. [PubMed: 15254941]

91. Gerhard A, Watts J, Trender-Gerhard I, et al. In vivo imaging of microglial activation with [11C] (R)-PK11195 PET in corticobasal degeneration. Mov Disord. 2004; 19:1221-1226. [PubMed: 15390000]

92. Turner MR, Cagnin A, Turkheimer FE, et al. Evidence of widespread cerebral microglial activation in amyotrophic lateral sclerosis: an [11C](R)-PK11195 positron emission tomography study. Neurobiol Dis. 2004; 15:601-609. [PubMed: 15056468]

93. Gerhard A, Neumaier B, Elitok E, et al. In vivo imaging of activated microglia using [11C]PK11195 and positron emission tomography in patients after ischemic stroke. Neuroreport. 2000; 11:2957-2960. [PubMed: 11006973]

94. Ramsay SC, Weiller C, Myers R, et al. Monitoring by PET of macrophage accumulation in brain after ischaemic stroke. Lancet. 1992; 339:1054-1055. [PubMed: 1349076]

95. Pappata S, Levasseur M, Gunn RN, et al. Thalamic microglial activation in ischemic stroke detected in vivo by PET and [11C]PK1195. Neurology. 2000; 55:1052-1054. [PubMed: $11061271]$ 

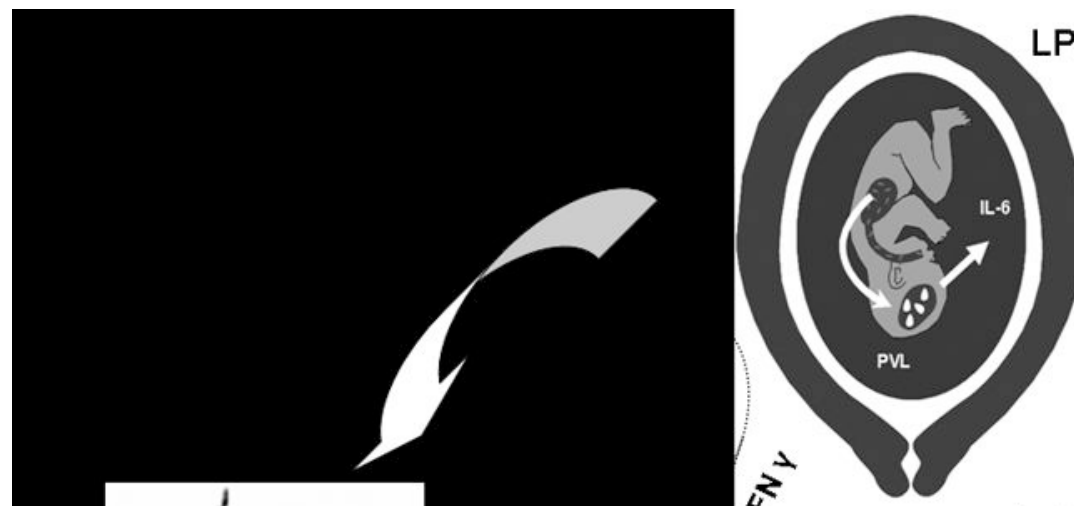

LPS
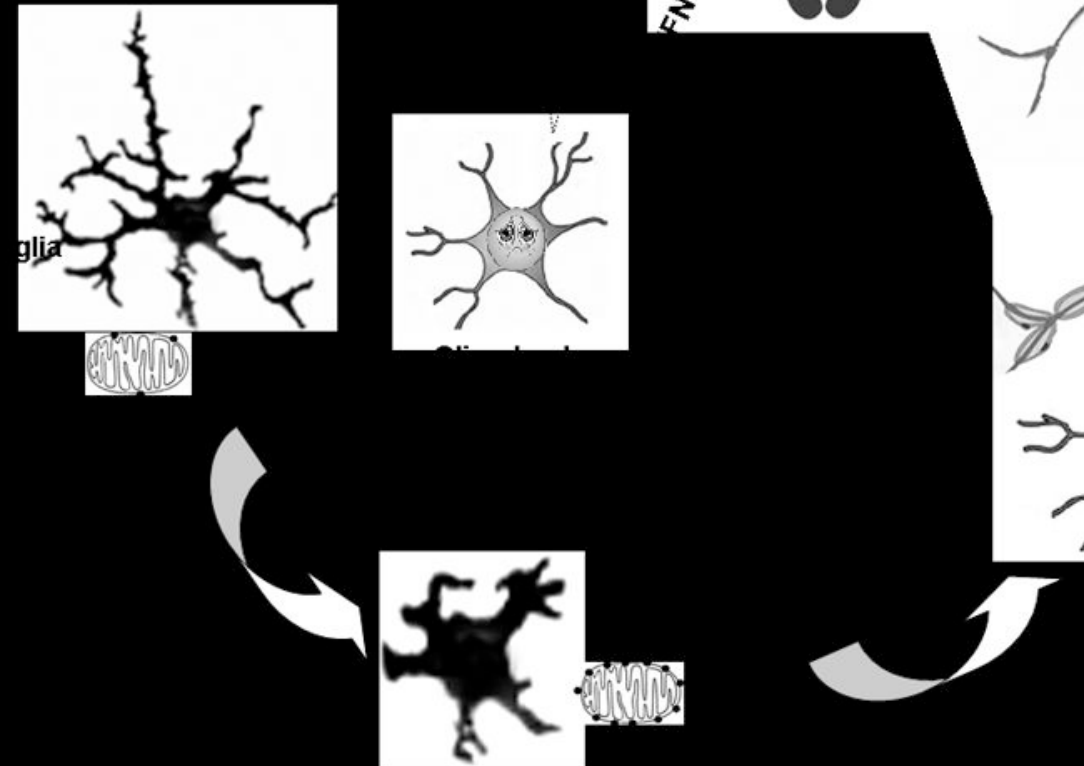

Figure 1. Proposed mechanism of oligodendrocyte and white matter injury in maternal intrauterine infection

The figure illustrates oligodendrocyte damage and microglial activation in response to cytokines following Lipopolysaccharide (LPS) exposure in the mother. LPS exposure in the mother following maternal intrauterine infection results in the release of pro-inflammatory cytokines. These cytokines may cross the blood brain barrier resulting in the activation of the microglial cells resulting in a change in morphology to an amoeboid form from a more ramified form. The activated microglia over-express peripheral benzodiazepine receptors (PBR) located in the outer wall of the mitochondria that can be imaged using [11C] (R)PK11195 by PET. Release of reactive oxygen species, reactive nitrogen species and cytokines by the activated microglia may lead to the arrest of oligodendrocyte progenitors. Inability of oligodendrocyte to produce myelin may subsequently lead to hypomyelination of neurons and white matter injury causing periventricular leukomalacia. 

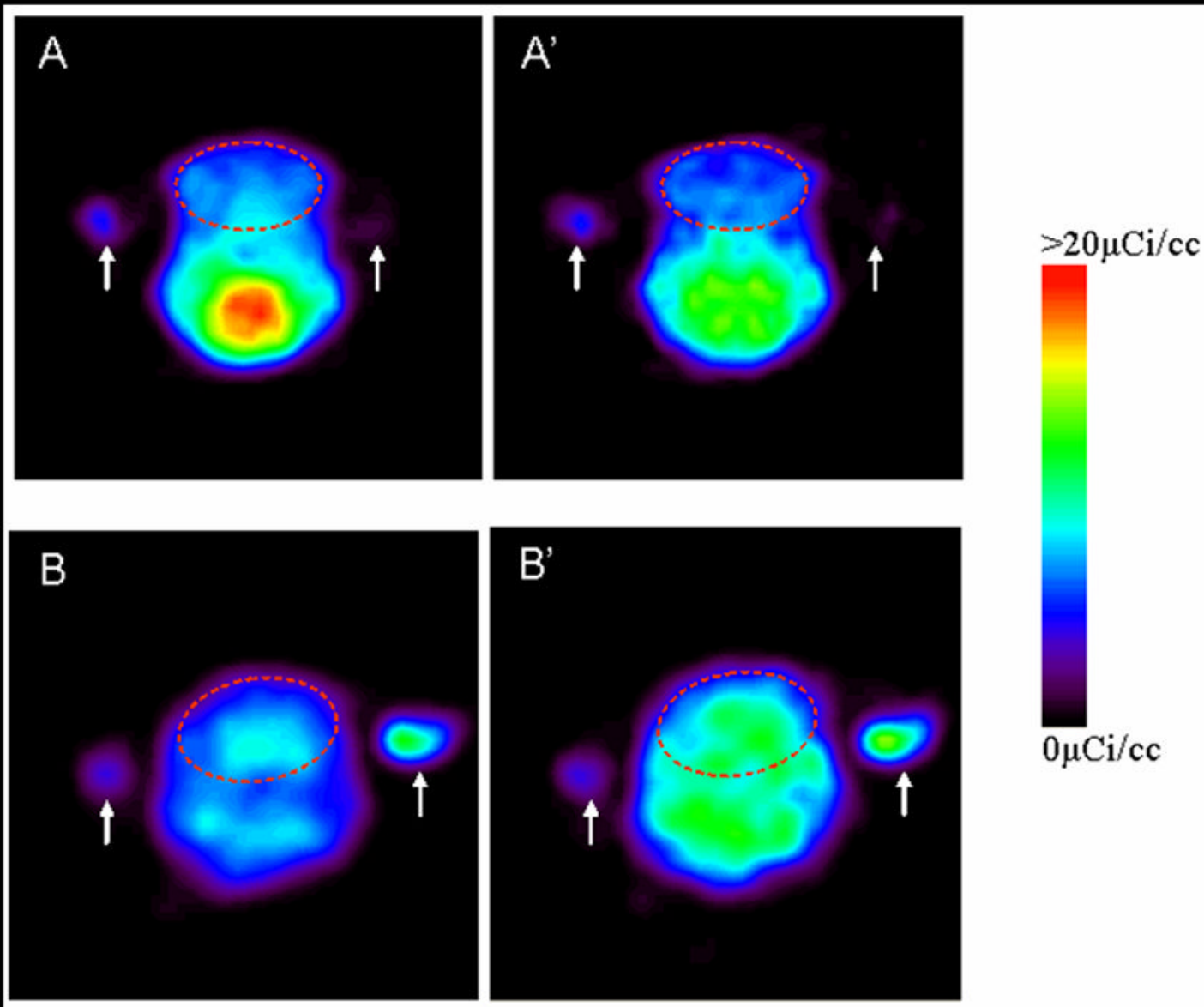

Figure 2. PET images of $\left[{ }^{11} \mathrm{C}\right] \mathrm{PK} 11195$ uptake in coronal sections of the rabbit brain for the first 10 minutes of the scan and the last 10 minutes of the scan at day 1 of life

3D ROI (indicated by red dotted lines) were drawn for the whole brain. The activity in the brain decreases over time for the saline injected control pups from 0-10 minutes of the scan when compared to 50-60 mins of the scan, while it increases over time for the newborn rabbit pups exposed to endotoxin in utero indicating specific binding of the tracer to activated microglial cells in the endotoxin exposed pups. White arrows indicate fiducial markers used for co-registration of PET with MRI images. 

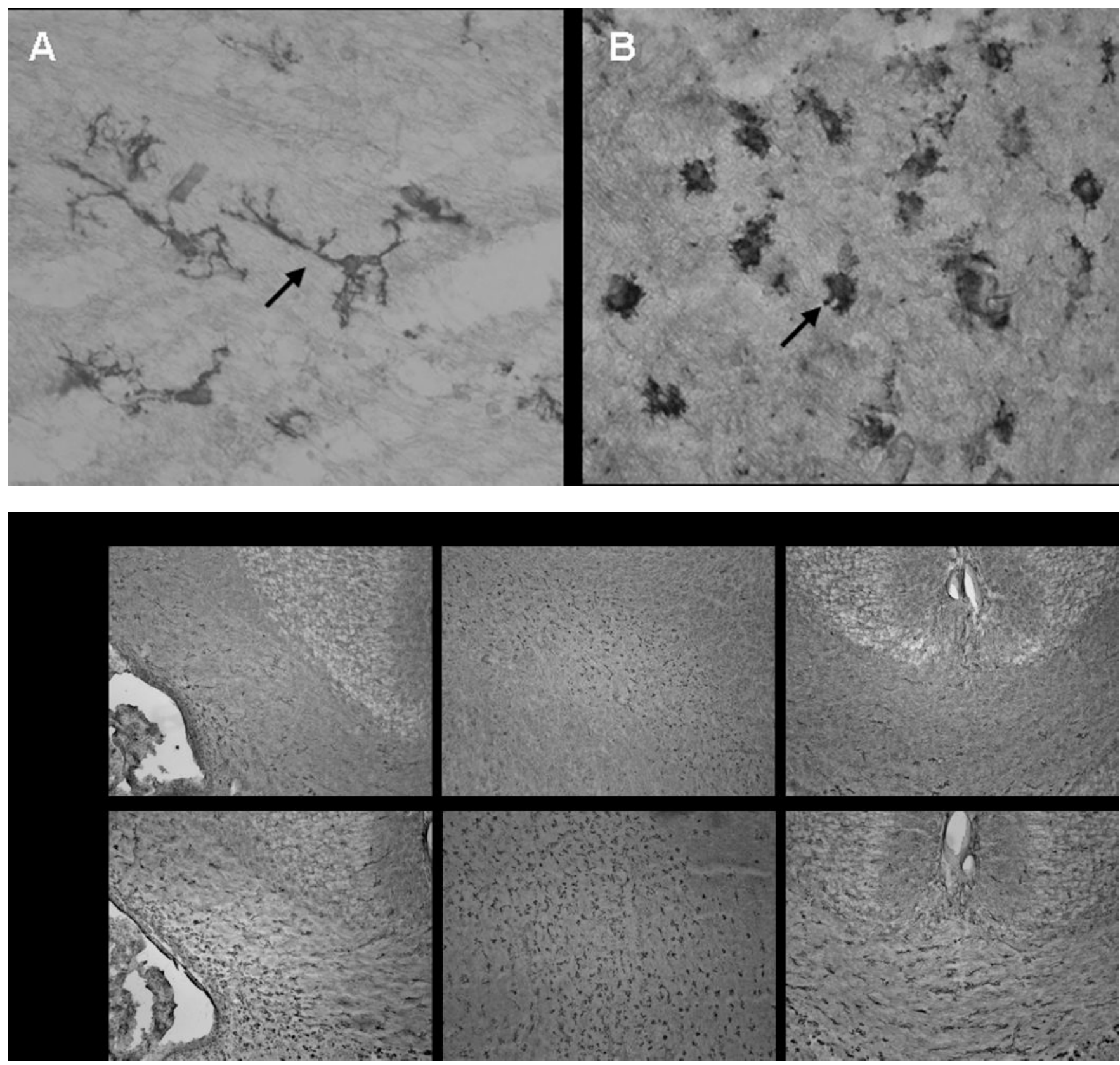

Figure 3.

a. Tomato lectin staining of microglial cells in postnatal day 1 brain of rabbit kits born to dams injected intrauterine with saline (control) (A) and 20ug/kg LPS (endotoxin)

(B).

Microglia in the control group exhibits ramified morphology (A, arrow) whereas in the endotoxin group the processess are shorter and thicker(B ,arrow). An increase in the density of amoeboid microglial cells in the endotoxin treated group was noted when compared to the control group.

b. Tomato lectin staining of microglia in postnatal day1 control and endotoxin exposed kits. 
Representative images indicate a robust increase in microglial cells along the border of lateral ventricle, internal capsule and corpus callosum in the endotoxin kit when compared to control. 
Table 1

Imaging of Peripheral benzodiazepine receptors in human neuroinflammatory disorders:

\begin{tabular}{|c|c|c|}
\hline $\begin{array}{l}\text { Neurological } \\
\text { Disorder }\end{array}$ & References & Findings on PET Scan \\
\hline \multirow[t]{3}{*}{ Alzheimer's Disease } & Okello et al.; $2009 .^{80}$ & $\begin{array}{l}\text { Increased }\left[{ }^{11} \mathrm{C}\right](\mathrm{R}) \mathrm{PK} 11195 \text { uptake was seen in } 38 \% \text { of patients with } \\
\text { mild cognitive impairment. Patients with increased cortical }\left[{ }^{11} \mathrm{C}\right] \mathrm{PIB} \\
\text { retention, a marker for } \beta \text { amyloid also had increased cortical }\left[{ }^{11} \mathrm{C}\right] \\
\text { (R)PK11195 binding in the cortex. }\end{array}$ \\
\hline & Edison et al. 2008. ${ }^{81}$ & $\begin{array}{l}{\left[{ }^{11} \mathrm{C}\right](\mathrm{R}) \mathrm{PK} 11195 \text { PET detected significant } 20-35 \% \text { increases in }} \\
\text { microglial activation in frontal, temporal, parietal, occipital and } \\
\text { cingulate cortices along with a } 2 \text { fold increase in }\left[{ }^{11} \mathrm{C}\right] \mathrm{PIB}-\mathrm{PET}\end{array}$ \\
\hline & Cagnin A. 2001.82 & $\begin{array}{l}\text { Significant increase in }\left[{ }^{11} \mathrm{C}\right](R) \mathrm{PK} 11195 \text { binding in the entorhinal, } \\
\text { temporoparietal, and cingulate cortex }\end{array}$ \\
\hline Schizophrenia & Van Berckel BN et al. 2008. 83 & $\begin{array}{l}{\left[{ }^{11} \mathrm{C}\right](\mathrm{R}) \mathrm{PK} 11195 \text { in total gray matter was increased in patients with }} \\
\text { schizophrenia. }\end{array}$ \\
\hline Multiple Sclerosis & Vas $A$, et al $\cdots 2008 .{ }^{84}$ & $\begin{array}{l}\text { Binding potential of }\left[{ }^{11} \mathrm{C}\right] \text { vinpocetine to PBR was found to be greater } \\
\text { than that of }\left[{ }^{11} \mathrm{C}\right](\mathrm{R}) \mathrm{PK} 11195\end{array}$ \\
\hline \multirow[t]{3}{*}{ Huntingtons Disease } & Tai, Y et al $\cdots 2007.85$ & {$\left[{ }^{11} \mathrm{C}\right](\mathrm{R}) \mathrm{PK} 11195$ binding in striatal and cortical structures } \\
\hline & Pavese $\mathrm{N}$ et al $\cdot 2006 .^{86}$ & Significant increase in striatal $\left[{ }^{11} \mathrm{C}\right](\mathrm{R}) \mathrm{PK} 11195$ binding was observed \\
\hline & $\begin{array}{l}\text { Messmer, K.,\&Reynolds,G. P, } \\
\text { 1998. }\}^{87}\end{array}$ & Increased uptakeof $\left[{ }^{11} \mathrm{C}\right](\mathrm{R}) \mathrm{PK} 11195$ in putame and, frontal cortex. \\
\hline \multirow[t]{2}{*}{ Parkinsons Disease } & Gerhard, A et al. $2006 . .^{88}$ & $\begin{array}{l}\text { Increased mean levels of }\left[{ }^{11} \mathrm{C}\right](\mathrm{R}) \mathrm{PK} 11195 \text { binding in the pons, basal } \\
\text { ganglia and frontal and temporal cortical regions }\end{array}$ \\
\hline & Ouchi, Y et al. $2005 .{ }^{89}$ & $\begin{array}{l}{\left[{ }^{11} \mathrm{C}\right](\mathrm{R}) \mathrm{PK} 11195 \text { binding potential in the midbrain contralateral to the }} \\
\text { clinically affected side were significantly higher in PD }\end{array}$ \\
\hline Progressive supranuclear palsy & Gerhard A, et al. $2006 .^{69}$ & $\begin{array}{l}\text { Increased mean }\left[{ }^{11} \mathrm{C}\right](\mathrm{R}) \mathrm{PK} 11195 \text { binding in the basal ganglia, } \\
\text { midbrain, the frontal lobe, and the cerebellum }\end{array}$ \\
\hline \multirow[t]{2}{*}{ Corticobasal degeneration } & Henkel, K et al. 2004. ${ }^{90}$ & $\begin{array}{l}\text { Increased }\left[{ }^{11} \mathrm{C}\right](\mathrm{R}) \mathrm{PK} 11195 \text { binding in the right putamen and the right } \\
\text { thalamus, right pallidum, right substantia nigra, , and caudal pons }\end{array}$ \\
\hline & Gerhard, A et al. 2004. ${ }^{91}$ & $\begin{array}{l}\text { Increased mean }\left[{ }^{11} \mathrm{C}\right](\mathrm{R}) \mathrm{PK} 11195 \text { binding in the caudate nucleus, } \\
\text { putamen, substantia nigra, pons, pre- and postcentral gyrus, and the } \\
\text { frontal lobe }\end{array}$ \\
\hline Amyotropic Lateral Sclerosis & Turner, MR et al. $2004 . .^{92}$ & $\begin{array}{l}\text { Significant increase in uptake of }\left[{ }^{11} \mathrm{C}\right](\mathrm{R}) \mathrm{PK} 11195 \text { in the motor cortex, } \\
\text { pons, dorsolateral prefrontal cortex and thalamus }\end{array}$ \\
\hline Multi System Atrophy & Gerhard, A et al. 2003. ${ }^{56}$ & $\begin{array}{l}\text { Increased }\left[{ }^{11} \mathrm{C}\right](\mathrm{R}) \mathrm{PK} 11195 \text { binding was primarily found in the } \\
\text { dorsolateral prefrontal cortex, putamen, pallidum, pons, and substantia } \\
\text { nigra }\end{array}$ \\
\hline \multirow[t]{2}{*}{ Ischemic stroke } & $\begin{array}{l}\text { Gerhard et al., 2000; Ramsay et } \\
\text { al., } 199293,94\end{array}$ & Increased $\left[{ }^{11} \mathrm{C}\right](\mathrm{R}) \mathrm{PK} 11195$ binding in Cerebral cortex \\
\hline & Pappata et al., $2000^{95}$ & Increased $\left[{ }^{11} \mathrm{C}\right](\mathrm{R}) \mathrm{PK} 11195$ binding in Thalamus \\
\hline Brain Tumors & Black et al. $1990 .^{72}$ & $\begin{array}{l}\text { High specific binding of }\left[{ }^{3} \mathrm{H}\right] \mathrm{PK} 11195 \text { to human glial tumors was } \\
\text { demonstrated }\end{array}$ \\
\hline \multirow[t]{2}{*}{ Encephalitis } & Cagnin $2001^{82}$ & $\begin{array}{l}\text { Increased }[11 \mathrm{C}](\mathrm{R}) \text {-PK11195-PET was observed within the affected } \\
\text { limbic system and additionally in areas connected to the limbic system } \\
\text { by neural pathways, including the lingual gyrus in the occipital lobe } \\
\text { and the inferior parietal lobe }\end{array}$ \\
\hline & Banati RB $1999,{ }^{26}$ & $\begin{array}{l}\text { Increased binding of }[11 \mathrm{C}](\mathrm{R})-\mathrm{PK} 11195 \text { in patients with Rasmussen's } \\
\text { encephalitis throughout the affected hemisphere }\end{array}$ \\
\hline
\end{tabular}

